DÁNIEL DEÁK*

\title{
Taxation of the Financial Sector: Robin Hood Taxes and Regulatory Framework
}

\begin{abstract}
The so-called bank levy-a tax levied on bank leverage-has been proliferated to date. They are the product of reacting to the global financial crisis that started in the autumn of 2008. Therefore, they can only be understood in the context of the crisis. Since one or two decades, the financial industry has produced much innovation that is to be reflected in taxation. The application of bank levy is thus the result of the reforms initiated in the sphere of financial regulation rather than tax law. Financial and tax laws are different from each other in many respects, however, as it will be discussed below where the constitutional background for the introduction of financial taxes will be explored.
\end{abstract}

Keywords: bank leverage taxation, Robin Hood taxes, ex ante and ex post measures

In this paper, bank levies; one of the newly introduced financial taxes-are in the centre of interest. In this respect, the paper concerns

- policy options and regulatory framework;

- detailed policy matters; and

- justification issues.

More precisely, it is discussed below:

- why and how was it necessary, following the global financial crisis, to introduce a bank levy and other new means of taxation in the financial sector;

- how much is ethics relevant to the conduct of the participants of financial markets, and what about the imbalances of virtualised financial markets;

- how can the meaning of the particular legal techniques be revealed that are applicable to the financial sector as para fiscal charges (corrective taxes to be adjusted to the envisaged externalities, or steering duties as compared to the non-tax tools of social control);

- how can the commercialisation of morality be reflected in the special financial taxes as Robin Hood ones;

- what is the regulatory framework for bank leverage taxation;

- what are the regulatory policy issues in detail, in particular, how can excessive finance be identified for tax purposes;

- how can a bank levy be justified as a product of innovation in tax law, in particular, what about tax incidence, the constitutional background, the issues of debt bias and double charging; and

- how is it possible (or is it possible any way) to reconcile the contrasting views on financial taxes of the business community, represented by tax lawyers, on the one hand, and the critics of macro economics, on the other one.

* Professor of Law, Corvinus University of Budapest, H-1093 Budapest, Fővám tér 8. E-mail: daniel.deak@uni-corvinus.hu 


\section{Post-crisis regulatory design}

\section{(i) Tackling volatility, opacity and illiquidity}

The initiatives to be discussed in this paper to introduce new taxes in the financial industry are a by-product of the global financial crisis that has been apparent in the autumn of 2008 . The crisis is due to financial innovations that have been designed to intensify financial activity. The result of it has been financial hyperactivity. This is what has been considered to date as a matter of externalities. They suggest difficulties that have been associated with the increase in the financial markets of systemic risks. The new taxes are precisely designed to address these externalities. Innovations of the financial market have been followed by innovations, now appearing in tax design.

The global financial crisis can be characterised by the features of reflexivity, virtuality and self-generation. According to George Soros, the economy that has underwent the current crisis can be characterised ${ }^{1}$ by the following features:

(i) The crisis economy is reflexive in the sense that financial market prices affect through bubbles the fundamentals that are supposed to be reflected in the market prices themselves.

(ii) It has produced new layers of reality as substantive economic claims have been all the more monetized and securitised. This is to virtualise the real economy. For instance, new generations of securities appear, based on the restructuring of financial claims through intermediaries like special purpose vehicles ("SPVs"). They are not really supported by fresh capital. They are only the result of holding tranches of restructured claims that are used as a security for the issue of a new generation of securities. New financial products do not derive from additional savings. Yet, they are able to produce increase in capital, even if the capital created this way represents novelty in accounting terms only.

(iii) The crisis economy is of self-generating nature, that is, autopoietic, because capital markets, producing a variety of composite and derivative financial products, are able to operate according to the rules they have developed themselves like in the world of cybernetics. As a result of the new layers of reality, financial markets are able to generate themselves from scratch. Self-generation has meant the development of investment projects that have proven to be bubbles. Then, the inflated market can collapse inadvertently.

The global financial crisis requires special legal and policy measures to deal with the problems arising from the crisis. The crisis suggests reflexivity in measuring the performance of financial and real economies, the amplification of the schemes arising from the restructuring of financial claims, and self-generation of investment schemes. It also constitutes a framework, within which the scope of taxation can be demarcated.

The new taxes are addressed to the externalities arising from the above-mentioned features:

(i) They are designed to alleviate financial market movements. In particular, it can be hoped that the introduction of new taxes will be able to mitigate price volatility, making the formation of prices more realistic.

1 Soros, G.: The New Paradigm for Financial Markets: The Credit Crisis of 2008 and What it Means. PublicAffairs, New York, 2008. 
(ii) Investors are less protected in the instance that the financial environment becomes opaque due to the artificial creation of capital, and to the discrepancy that can be experienced in the indicators of the various tranches of newly created capital. The new taxes that are aimed at the components of assets, liabilities, activities, or at transactions that are tainted by financial hyper-activity could be helpful with removing these anomalies.

(iii) New taxes are to be introduced, following the failed expectation that financial markets tend to equilibrium. These taxes could be able to break the process of financial self-generation through bubbles. They can thus be helpful with de- and reconstructing financial markets.

According to the criticism of the crisis economy, it has been illusory to assume that

- trade with high frequency would have contributed to more efficient price formation;

- financial innovation would have made financial markets more complete, and improved transparency in the management and distribution of risks; and

- financial hyperactivity would have ensued more liquidity. ${ }^{2}$

From this perspective, the introduction of the tax related tools of financial regulation would not really be a technical problem. Arguably, it is rather a matter of political decision to decide in favour of such taxes. ${ }^{3}$ A financial transaction tax is technically feasible, and morally right. ${ }^{4}$

Without getting engaged in dispute with the above criticism, it should be clear from the present paper that it is unfortunately not only a matter of good intentions to solicit the introduction of special taxes applicable to the financial sector. As they are expected to be flexible due to the changing economic environment, they inadvertently lead to legal uncertainty. From the perspective of legality, it is thus not obvious at all how the new taxes can be put in place.

\section{(ii) Relevance of ethics to the individual conduct of financial managers and to the systemic operation of financial markets}

The application to the conduct of financial managers of ethical considerations seems to be difficult. At a glance, individual bankers cannot be blamed that they would be engaged in fraudulent schemes or would deceive their clients by overestimation, violating the standards of sobriety, while seeking to maximise shareholder value. It is their duty to act on behalf of their clients, seeking their benefit. Restructuring of financial claims is rational because by means of such activity it is possible to enhance values that were hidden before. The system of excessive finance may nevertheless tend to go wrong.

The ethical standard of fair valuation does not seem to be broken upon restructuring of financial claims, producing CDOs (collateral debt obligations), yet securitisation may result in volatility in prices, opacity in operation, and illiquidity upon exit. Carrying out individual financial transactions may be ethically unobjectionable even if the system towards which individual actions tend goes wrong. It is then a matter of ethical responsibility to stop functioning of such a system once it has proved wrong.

2 Schäfer, D.: Financial Transaction Tax Contributes to more Sustainability in Financial Markets. Intereconomics, (2012) 2, 76.

3 Schulmeister, S.: A general financial transactions tax: Strong pros, weak cons. Intereconomics, (2012) 2, 89.

4 Buckley, R. P.: A financial transaction tax: The one essential reform. Intereconomics, (2012) $2,103$. 
Opportunism of market behaviour may be revealed individually, in group, or even by large organisations, including public bodies. Human motivation may still exceed pure market calculations. Great business should survive in the long run, and is based on the idea that a good contract serves the balance of interests with all contracting parties. Being subject to positional goods, the use of which is exclusive, and to economic rewards that are to be granted under the strict equivalence principle of "do ut des" represent the human constraints on the market behaviour. Disregard of these constraints is certainly unethical. It is not yet easy to identify them in the daily course of business.

From a moral point of view, the individual market player cannot be criticised where he or she complies with the professional standards in conformity with the operation of free competition. The starting point for moral responsibility is for the market player that he or she should be aware of the human constraints on the operation of markets. Then, the market behaviour must be adjusted (completing the profit motive by the idea of the economic, social and ecological balance of households, by seeking to go beyond the scope of market opportunism, etc.).

A good example for the difficulty one has to come across, while calling into account ethical requirements in the business life is tax avoidance. This is the abuse of law. However, no single legal provisions are violated in this case. Neither are here professional standards disregarded. It is then more than difficult to raise ethical issues. Ethics represents metajuridical values, the enforcement by legal means of which would be dysfunctional.

In the process of the application of law, formal rationality cannot be dispensed with. This means that the individual conduct can only be evaluated to the extent that it is imputable to the social command as negotiated by legal norms. Then, it is possible to conclude whether the conduct under discussion does or does not comply with law. Unfortunately, law reflects its own contradiction to the extent that it is unable to manage the problems arising from the conduct, which does not break a particular legal rule, but which perverts the system of legal rules as a whole. It comes from this that tax avoidance can be approached by means of non-law only that makes an avenue to ethics. Yet, law as a system resists the evaluation of the individual conduct by means of other than law.

The respect of moral values is presupposed by the choice between the values of good and evil from the perspective of morality. Big organisations survive thanks to more formal rules. Furthermore, the state-operating in the centre of official life-is in a position of introducing laws. As markets are only subject to laws and to professional rules of conduct, the simple operation of markets does not raise the question of morality. ${ }^{5}$ The choice of moral values is possible if market participants elevate themselves over their interests that are rooted in rude market positions. Observation of the standards of good faith and due diligence does not yet mean ethical choice, the precondition of which would be to go beyond the scope of a market decisions, exercising criticism if necessary over the market oriented conduct. An example for this is investing in ethical or ecological funds. Such a decision goes far beyond the standards of due diligence.

The lesson that can be drawn from the global financial crisis is that the assumption that individual actions of the participants of financial markets tend to result in an optimal state of markets has not proven true. The reason for this is that seeking for shareholder-value has become the end instead of serving as a means of controlling the performance of the

5 Koslowski, P.: The Ethics of Banking; Conclusions from the Financial Crisis. Springer Science+Business Media B.V. 2011, Chapter 3: The ethical economy of the capital market. 36. 
company that operates for the benefit of its stakeholders. Financial service-providers are expected to serve their customer, eventually arising from the real economy, who should not seek to maximise, but to generate profit.

In a market economy, it is crucial to achieve compatibility between managers and shareholders. At the level of owners and employees (finis operantis), maximisation of utility is acceptable. At the level of the company itself, good products are expected to provide to the consumer (finis operis). This means efficiency and effectiveness in the supply of goods and services. Compatibility between the two factors makes it possible that the invisible hand of the market is working, at least from case to case. ${ }^{6}$

Where there is no balance between financial and real economy, there is no interaction either between the functions of serving the consumer and the profit motive. As a result, the invisible hand of market fails to operate. Where financial markets make themselves independent of the real economy, admitting to enjoy rewards that deviate from the rewards available in the rest of the economy, the state must intervene by means of taxation to restore the balance between financial and real economy, and to reinstitute equality in taxation. ${ }^{7}$

\section{(iii) Imbalances of virtualised financial markets}

Excessive finance may lose its functionality. One can still hardly predict the time when the borderline of ethically acceptable values is transgressed. Financial speculation cannot be condemned as such. It can cause harm to communities, however. It can only be recognised from time to time whether participation in certain transactions can be ethically tenable or not, and if so, in what conditions.

Banking credit results in granting a loan to business or consumer households, usually as deposit money. That is, the debtor does not use cash to meet obligations, but transfers his or her claims arising from the banking credit received. As money is a soft product of economy, based on mutual trust, the scope of banking credit can be extended to ethical lending. Technically, it is without any serious difficulty to switch over from instrumental rationality to reciprocity in the process of consolidating money as a means of payment. Insofar as money is a means of social convention, the law related aspect of money is of striking importance (as comparable to the commodity based side of the social use of money).

It is not precluded that money serves broader goals than just the maximisation of individual profit. Money would then be able to meet the need of the stakeholders, broadly speaking, arising from need of the poor, or from the necessity that ecological projects must be financed. Money is considered in this respect as a means of the responsible allocation of social resources. A loan a bank may grant can be extended to other than the strict calculation of profit because the lender's profits should consist not only of unilateral economic benefits, but also of the needs of the social environment, and of the contribution to social and ecological welfare. ${ }^{8}$

As the lending policy of easy money significantly contributed to the financial crisis starting in the autumn of 2008, financial and tax regulations have to discipline banks that

${ }^{6}$ Ibid. Chapter 10 Financial Overstretch: The Epochal Disturbance of the Invisible Hand of the Market by the Financial Industry. 147.

7 Ibid. Chapter 10 Financial Overstretch: The Epochal Disturbance of the Invisible Hand of the Market by the Financial Industry. 151.

8 Ibid. Chapter 2: The ethical economy of the credit market. 29. 
felt to be compelled by competition to loosen their credit policy standards. It seems to be even more problematic that a large number of people accepted a loan of mortgage for second or third homes. They did not really borrow because they would have needed credit. They simply did it because the credit available was cheap. Hence, banks can be called into account for their negligence. Their customers can be reproached even more for the covetousness and materialism they showed. They fell prey to their naive belief in laws of the market economy. Such a conduct may be disciplined, or even reprimanded, not to mention that a large number of them lost the property they obtained through a discounted loan. It seems to be reasonable to hit by legal or tax regulations such behaviour of both lenders and borrowers.

The policy of easy money leads to the confusion with customers of what is needed with what is cheap. They make a mistake because they orient themselves according to the instrumental rationality of market economy even where it would be required to come back to the basic function economy, aimed at achieving balance between their needs and the sources that are scarcely available. Under the policy of easy money, financial serviceproviders produce extraordinary cases, from which they can benefit, and even their customers seem to benefit. The process of creating easy money is not endless, however.

The expansion of financial markets could not be stopped due to the hyper incentivising of bank managers and, more importantly, for lack of the effective constraint of market demand on the performance of financial markets. The creation of deposit money through lending can only be constrained by competition of banks with each other and, finally, by the restricted performance of the real economy. Virtualisation of the functioning of financial markets has loosened the constraint of demand, eventually to be determined by the real economy's capacities. This also means isolation from the trends of real economy.

The erosion of the constraint of market demand has started already through the collectivisation of capital, the arising socialising function of finance capital, ${ }^{9}$ and the emergence of the "technostructure" 10 when the managers had the company get interested in expanding the size of their business rather than in maximising its profit. In the circumstances of the concentration of capital and de-concentration of ownership, the special skills of managers have deeply been integrated into the process of business administration. This happened in developed countries already at the turn 19th and 20th century. When the "technostructure" makes corporate owners interested in increasing their business in size, economic expansion suggests the increase of business in size that results in turn in increasing the power that can be exercised over the growing business. This process of growth can only be stopped when the scarcely available natural resources are depleted. The barrier of market demand does not play here a key role. Although managerial capitalism and technostructure declined in the 1980s, the constraint of demand has not been toughened in the financial markets that started working globally.

Virtualisation of financial markets taking place through the creation of capital in the process of restructuring of financial claims and securitisation through SPVs has ensued that the constraints of market demand have been elusive. The participants of financial markets have been driven away by the illusion that there are no constraints on the creation of money, and that the real economy should automatically react to the creation of additional deposit money by catching up with it, increasing production. The global financial crisis has divulged

9 Hilferding, R.: Finanzkapital. Wien, 1947. 514.

10 Galbraith, J. K.: The new industrial state. Boston, 1967. 71. 
imbalances between financial and real economy markets. Hyper-capitalism has transformed itself into its own opposite: capitalist economy has been developed where capital can be created without raising additional funds from the real economy. The mirage of financial innovation has yet been over. As this happened while causing significant harm to the society, the state should intervene by means of follow-up financial regulation and taxation.

In the circumstances of virtualised financial markets, the process of creating easy money seems to be endless. It will be stopped, however, if it reaches a psychological barrier, that is, public trust ends. Then, the economic and social environment ceases to meet the expectation that the newly created money would be offset by the additional performance of real economy. This is the time when bubbles burst out.

The economy where economic survival does not depend on the barrier of market demand, but on the barrier of trust cannot be considered capitalistic. In this instance, capitalism turns into non-capitalism where power arises from the exploitation of the monopoly of the special skills of financial managers. As their power is not established on private property, but on the monopolisation of special skills, they also constitute a type of "technostructure".

In a capitalist economy, there is a balance of prices with the respective exchange values. The use of private property makes it possible to exploit the worker, expropriating part of the value he or she has produced. This is the surplus value ("Mehrwert" with Marx), which is no longer necessary to reproduce his or her skills. In virtualised financial markets, there are financial managers who hold the power of monopolising their skills. In extra circumstances, they can achieve extra rewards. This can only take place for lack of the balance of prices with the respective exchange values. Furthermore, financial market participants pretend to create new values. This is phantasm, however. They add mock value to the economy through the creation of additional money. This will not turn out, however, as long as the bubbles developed will not burst out.

Like in the economy subject to the power of technostructure, the economy of virtualised financial markets cannot be considered to be capitalistic either. The reason for this is that the laws of capitalist speculation are so much intensified that they convert themselves into non-capitalism. This is a process where capitalism repeals and preserves itself at the same moment (the dialectics of this development can be best described by the Hegelian term of "aufhebend").

\section{(iv) Corrective taxes in the context of the legal techniques of social control}

The legal regulation on the taxation of the financial sector is a subject that can be put in a broader context at least in two respects. First, it is worth studying it as the taxation of financial instruments that can be compared to corporate taxation, VAT and payroll (labour income) taxation. The tax treatment of financial instruments can be examined with particular regard to transaction taxes, in particular, to securities transaction taxes. The benefit of the comprehensive discussion of the financial sector taxation would be that the taxation of the financial sector could be compared to that of the non-financial sector. ${ }^{11}$ Second, tax measures that are applicable to the financial sector can be considered as corrective taxes that can be

11 Review of current practices for taxation of financial instruments, profits and remuneration of the financial sector, PwC TAXUD Working Paper No.31, Brussels, 6 June 2012. 
compared to the other crisis related means of legal regulation, in particular to civil liability, administrative law and criminal law sanctions. ${ }^{12}$

The corrective nature of the tax related tools of legal regulation can be compared to normal taxes that are not entrusted with functions of other than raising funds. For many years, corrective taxes were applied quite narrowly. For instance, they can be applied to polluting activities. Another example for their application is the use of excise duties that are designed not only to raise funds, but also to influence undesirable consumer habits. It is new that they are being proliferated in the banking sector. ${ }^{13}$ It is easier to design corrective taxes than apply regulations insofar as it is less required for application to know. Namely, it is enough to be informed of the estimated harms of the activity to be addressed that must be eliminated, not to mention the probable benefits. ${ }^{14}$ The present paper focuses on the taxes applicable to the financial sector (operating mainly as financial stability contributions or bank levies). Non-tax regulatory tools are thus not dealt with below unless they are closely connected with tax related measures, the function of which cannot be explored without reference to non-tax law measures.

It is an easy approach to the problem of regulatory design that may react to the financial crisis that legislative responses are to be substantiated by reference to the effectiveness and economic efficiency of the legal regulation. From this angle, the cost \& benefit method can be highlighted, according to which the various means of legal regulation can be evaluated. ${ }^{15}$ One must be aware of the limits on the application of this method of evaluation, however. The performance of legal institutions can be measured by means of economic efficiency, of course. This is the responsibility of a doctrine of law \& economics. The global financial crisis has manifested, however, in market imperfections. Thereafter, one must be cautious, or rather critical, about the methods that are based on the assumption of economic efficiency.

The quality of legal regulation can be assessed from the viewpoints of various legal techniques. One can learn in this respect from Robert Summers who has explored the legal nature of the various techniques of social control (i.e. remedial, penal, administrative, public benefit oriented, and private arrangements related techniques can be enumerated). ${ }^{16}$ Being loyal to the comprehensive approach to law of Summers, the observer must arrive in the end of a process of the evaluation of legal tools at the justification by integrity of law.

Due to market imperfections, business considerations must be critically examined from the viewpoint of macroeconomics. A legal analysis should suggest more than simply reflect business considerations. It should assist market participants and, in particular, those who benefit from market services in learning from the critics by macroeconomics of the global financial crisis. Having encountered the post-crisis developments, the lawyer should seek to find solutions while designing legal tools in an environment where the basic legal

12 Hellgardt, A.: Comparing apples and oranges? Public, private, tax and criminal law in financial markets regulation. Max Planck Institute for Tax Law and Public Finance, Working Paper, No. 2012-04, Munich, June 2012.

13 Corrective tax is a means of regulation that is connected to the estimated harm rather than to the harm actually done. See Shavell, S.: The optimal structure of law enforcement. Journal of Law and Economics, 36 (April 1993) 1, Part 2, 284.

14 Shavell: op. cit. 285.

15 Hellgardt: op. cit. 3.

16 Summers, R. S.: The technique element in law; A tribute to Hans Kelsen. California Law Review, 59 (1971), 745. 
principles like the rule of law and the equality before the law are faded during the permanent adjustments to be made to the abrupt changes arising from externalities.

With the emphasis placed on economic efficiency and on the application of the cost \& benefit method, the option of civil liability is obviously preferred to penal sanctions, administrative regulations or corrective taxes. This may still be problematic first because it relies on the assumption of market perfection, whether it is true or not. Second, other options that could arise from the logic of discourse and cooperation between market participants are not revealed.

The parties affected by legal regulation should seek for an elbow room where a common language can be developed, through which the values can be acknowledged that could be guiding in a particular case. Delegation of the regulatory power to Community bodies can also be helpful. Even Community law is, however, in a need of the fringe means of control, like blanket law and comitology. The market players themselves should be responsible for creating an atmosphere, in which agreements can be reached from case to case.

While analysing the operation of financial markets, the examples of false investment advice, insider trading and the disregard by bank managers of moral hazard do not really seem to be able to explore the problem of financial markets that-as a result of reflexivity, virtualisation and self-generation as explained by George Soros-contribute to the volatility of the pricing of both financial products and fundamentals, lack transparency and reduce liquidity, respectively. The appearance of the new generations of securities without being supported by fresh capital and the autopoietic nature of the expansion of financial markets are not problems that would have been generated by the malpractice of bank managers through misinformation, insider trading or the negligent treatment of moral hazard. It is not the fault of the service-providers themselves, but it is due to the operation of the whole system of financial markets that service-providers are easily able to enter a new segment of deals, but can hardly able to exit.

The option of civil liability as a regulatory tool can be associated with the legal technique of private arrangements as interpreted by Summers. The great benefit of such a technique is the facilitation of contracting parties with a number of legally recognised options. In case of the enhanced application of directive rules, the role of judiciary is also conspicuous. It may then largely depend on the court seized in a particular case how the relevant law will be enforced. The civil liability-based method of legal regulation may thus give much flexibility in the management of legal problems.

It is the constraint on the use of this regulatory method, however, that it is bound to the equivalence with each other of the individual performance of one contracting party and the consideration made for it by the other party. Markets cease to operate unless the principle of "quid pro quo" is operatively maintained. Market players may fail to achieve this balance some times, however. This is not because their conduct is defective or morally objectionable. Failure may simply happen because markets should reach a level of development to find solutions for the obligations developed before. Markets are not always complete, however. Reciprocity is superior to market-equilibrium in the instance that the performance made by one party to another one is not necessarily compensated to the first party, but consideration may widely be made in favour of third parties. This makes the relationship of parties free from the opportunism of the market-oriented conduct. 


\section{Taxation of the financial sector by means of Robin Hood taxes}

\section{(i) Commercialisation of morality, populism and corporatism in taxation policy}

As long as systemic risks cannot be securely maintained within the financial sector since the start of the global financial crisis, the interference of the public authorities with the operation of financial intermediaries seems to be inevitable. In line with the application of financial regulations, it seems also to be necessary to involve in the regulatory armoury the tax related tools of regulation. This suggests the introduction of corrective taxes. They can, however, be seen from an angle of criticism as well.

This criticism can be exercised not only on the ground that the economic criticism of the financial sector's performance is not fully sufficient, and that interference with the free market oriented operation of financial enterprises is arbitrary, and therefore unnecessary. Such a criticism can also be justified from the viewpoint that corrective taxes do not provide a solution that would be appropriate for crisis management. Instead, the corrective taxes of the financial sector could be depicted as the deterioration of the standard arsenal of tax policy. They should in this respect represent the commercialisation of morality. It is thus false morality, under which special taxes of the financial sector could be introduced. Hence, they might be not only inefficient and dysfunctional from an economic point of view, but they may also be immoral.

At the time of crisis, ideas and simple views may be capriciously raised to the level of ethical norms, and even legal provisions. Then the product of legislation could be assessed directly from a moral point of view. Such moral considerations may then replace the professional standards of systematic fiscal policy and legal doctrines. In such a case, morality will be confused with the dogmatics of law. Such an approach to law opens a door to the so-called Robin Hood taxes. ${ }^{17}$

From the viewpoint of Robin Hood style fiscal policy, taxes should not affect the ordinary people. They should instead be targeted at the rich. Although the taxation of the financial sector seems to avoid the ordinary people and addressed to the rich, this is not quite true. As the smooth operation of financial institutions is in the very interest of the public, failure to operate would directly hit the ordinary people. The burden of this failure must then be borne by the ordinary people. This way, a Robin Hood tax sounds well, but it is far from the quality of a systematic tax and legal policy.

Clearly, particular tax policies cannot really be justified by commercialised versions of ethical standards. It is also a question, however, if it is possible at all to raise ethical issues, while arriving at the assessment of tax policies. Truly, it is hardly possible directly to apply ethical judgments, while evaluating tax policies. This is because there is no public agreement what about good taxes are, or what is about the just behaviour a taxpayer has to pursue. Ethical considerations must be integrated into the professional standards. It is precluded that, e.g. a fiscal policy could be considered as ethical if it is failed from a professional point of view. However, as the global financial crisis has shown us again, the free market conduct cannot survive without the assistance of public institutions and, from this perspective, ethical considerations cannot be missed.

17 Beck, H.-Prinz, A.: Moralisierung in der Steuerpolitik: Was taugen die jüngsten Steuervorschläge? Wirtschaftsdienst, 90 (Dezember 2010) 12, 824. 
The commercialisation of ethics can be expressed in the field of politics as populism that can be described from the perspective of sociology by the following features: ${ }^{18}$

- the language of political discourse is not syntagmatic, but paradigmatic; that is, it is evocative rather than systematic;

- the public space organised by politics seems to be equivalent to particular political manifestations; and

- as these political manifestations are able to independently constitute ideological contents, what is representing may be exaggerated, compared to what is represented.

From the viewpoint of social psychology, populism can be characterised as follows: ${ }^{19}$

- populism is the reverse side of the ascetic behaviour that dictates us renouncement from the consumption of the goods that can be adjudged as evil; abandonment takes place through penance, suffering is manifested as reasonable and the individual refraining himself or herself from action can be glorified and spiritualised;

- under populism, the individual is pathologically inflated in a course of action where the empty space left due to the disrespect of professional values is to be replaced by authority, or even force;

- repression is proliferated, producing waste, the removal of which is only possible by the assumption of conflicts (in particular, by showing up scapegoats and fabricating conspiracies); and

- in the circumstances of populism, there is no more space for ethical considerations, morality can be replaced by Darwinism, and legal regulation by voluntarism.

The fiscal policy that is manifested in Robin Hood taxes is a kind of populism. In such a case, the legislator does not invest in legislation much preparatory work. This policy is rather of improvisational nature. The legislator negotiates particular political manifestations, while seeking to keep aside the ordinary people from the impact of taxation, and focusing on the rich, such as bankers and their institutions. While designing such taxes, professional standards may be replaced by voluntarist measures of fiscal policy.

Upon designing a Robin Hood tax, the ability-to-pay principle is complemented by the corporatism related idea that large organisations have their particular responsibility for financing public tasks. In particular, financial enterprises may be expected to contribute to the cost of their bail out to be financed by public funds. Financial service-providers may be bound to this responsibility even if they sustain losses. In this respect, it seems to be justifiable to levy on them taxes simply because these organisations are big enough. The size of organisation can thus be more important than the way, in which market-players operate. Robin Hood taxes are typically levied on companies operating in network industries. They appear not only in the financial sector, but also in the field of telecommunication or of the supply of energy. Other large organisations can also be involved, like pharmaceuticals. ${ }^{20}$

${ }^{18}$ Laclau, E.: Populism: What's in a name? University of Essex, Centre for Theoretical Studies in the Humanities and Social Sciences; Online papers, Colchester, 2005.

${ }_{19}$ Neumann, E.: Tiefenpsychologie und neue Ethik. Opus Magnum 2005, www.opus-magnum. de; Erstmals erschienen Zürich: Rascher, 1949, Paras 68, 78, 120, 122.

20 All these Robin Hood taxes can be found in Hungary. 
The state introducing Robin Hood taxes is willing to offer an alliance with the ordinary people (like the case was with "Forza Italia"). Such a state identifies itself as the guardian of the interests of the ordinary people. This alliance can only be interpreted in the political sphere, however, where professional values of a fiscal policy are usually subdued by political considerations. The policy of Robin Hood taxes can be justified by the criticism of the post-industrial mass society, representative democracy, and even of the idea of free competition. In this context, economic rationality must be reinterpreted. Public bodies should not be subordinated to the interests of free trade and fiscal discipline. Instead, they should be responsible for negotiating between the households of the public and private sectors. The large volume of tangible and intangible assets representing significant volume of knowledge can only be produced, and reproduced, if public bodies are involved in the process of socially organised production and distribution. The cost that must be paid for this is to levy special taxes, the rationale of which clearly deviates from the idea of fiscal neutrality.

\section{(ii) Emerging constraints on legislation during the financial crisis}

Robin Hood taxes are not only the product of the financial crisis, but also that of the legislation based on the above depicted commercialised morality that may prevail over the professional considerations of fiscal neutrality and legal certainty. There should still be constraints on the legal regulation that is either subdued by ideological and political considerations that debilitate the rule of law principle, or positive law can be dissolved in the values of natural and customary law, and social players are not provided by the state with comprehensive statutory law.

Constraints on the legal regulation can also be ascertained in another aspect of the mechanics of law, i.e. regarding "lex" and "ius". It is thus a question how much law can be enforced. ${ }^{21}$ This is a problem that has been acute in cases where the legislator does not have sufficient knowledge on the subject of legislation. It is in particular true in case of the new taxes of the financial sector that the legislator is not provided with the ability of omniscience. He or she is thus not able to predict events at the level of exactness that would be necessary to legislate in a proper manner. It can then occur that, at a certain point, law cannot be enforced. This way, law (lex) does not provide longer a basis for the exercise of subjective rights (ius).

The scope of legal regulation and moral conventions are eventually constrained both bottom up and top down. The bottom up borderline comes from the insufficiencies of a mass society. Masses can be easily influenced, and even manipulated. As observed by the psychologist, people may easily become in a crowd irresponsible. They can be pathologically subordinated to their leaders, and lose their sensibility to innovations. They can in a crowd be similar to the individual who is hypnotised or neurotic. They can feel to be in a flock of sheep where they lose their judgment and morality. ${ }^{22}$ The products of commercialised morality, resulting in Robin Hood taxes are adjusted to the sentiments and attitudes of such behaviour. From this perspective, Robin Hood taxes tend to suggest the end of law and morality.

${ }^{21}$ See more for that in Deak, D.: Neutrality and legal certainty in tax law and the effective protection of taxpayers' rights. Acta Juridica Hungarica, 49 (2008) 2, 178-180.

22 Freud, S.: Massenpsychologie und Ich-Analyse. Wien, 1921, 16, 18, 21, 23. 
Legal application can also be constrained top down. In certain conditions, people do not feel it necessary to rely on the conventions of this world. This is because they realise that both moral and legal norms lack absolute values. Due to this, the abuse of law cannot be stopped. Experiencing these insufficiencies, people are willing to substitute divine laws for the regulations of the secular world. This is a sphere of life where it is not necessary longer to rely on legal sanctions irrespective of whether moral and legal rules are supported by the morality that is deteriorated or not. It is not the responsibility of the lawyer to deal with these value judgments. They are still indispensable because moral conventions and legal rules are complemented by transcendental values that can only be found in this higher sphere of regulation. Bargaining is vital in a market economy-based society. However, neither equilibrium of individual expectations, nor balance of legal application can be reached without the consensus on noumenal values.

Tax liability must be established on statutory law, which is in the hard core of legal regulation. Tax law is designed to achieve fiscal neutrality. The more freedom from the fluctuations of daily politics the tax legislator enjoys, the better chances are for the adoption of tax law of good quality. The introduction of Robin Hood taxes, being as sectoral ones, clearly challenges fiscal neutrality. Concerns of horizontal equity can thus be significant.

Commercialisation of law contributes to the dilution of legislative techniques and standards, enhancing the disintegration of the tax law infrastructure. Where legal stability is missing, effectiveness in the protection of taxpayers, easy compliance and feasibility can also become doubtful. Legal application is centred on the issues of easy compliance and the effectiveness in the legal protection of taxpayers. Adjustment of the legislator to abrupt changes may reach an instance where not only "ex ante", but also "ex post" measures (e.g. claw back measures) may apply. This is to debilitate legality not only in following tax laws, but also in the field of tax legislation.

\section{Regulatory options and framework}

\section{(i) Regulatory options}

The basic pattern of a bank leverage tax is the financial stability contribution ("FSC") as proposed by the IMF. ${ }^{23}$ It is a special charge that could be introduced to contribute to the stabilisation of the financial market. It is different from the financial crisis responsibility fee ("FCRF") as proposed by the US President Obama. ${ }^{24}$ The latter is, although to be levied "ex ante", serves like an insurance fee. A claw back measure is based on the Dodd-Frank Bill of 22 July $2010 .{ }^{25}$ According to it, the Federal Deposit Insurance Corporation ("FDIC") shall charge one or more risk-based assessments if such assessments are necessary to pay in full the obligations issued by the FDIC to the Secretary within 60 months of the date of issuance of such obligations.

It can be compared to a legal institution called in the practice of German-language countries as "Umlage". The point to the latter is that the burden arising from certain

${ }^{23}$ A fair and substantial contribution by the financial sector, IMF final report for the G-20, June 2010.

24 The White House Office of the Press Secretary, January 14, 2010.

25 Dodd-Frank Wall Street Reform and Consumer Protection Act, Pub. L. No. 111-203 (H.R. 4173), 124 Stat. 1376. 
externalities must be allocated to the participants affected by the risks. An example for this is the cost of sick payment or maternity leave to be shared between the state, the employer and the employee. Another example for such cost-sharing is the cost of the facilities of green energy to be shared between the public and those individuals who benefit from these facilities. The cost of car insurance can also be mentioned that can be shared between the public and car users.

A Commission Communication on financial sector taxation is also noteworthy. ${ }^{26}$ It envisages the options of a financial transaction tax ("FTT") and a financial activity tax ("FAT"). FTT is not to be charged on financial institutions, but on specific transactions. FTT is to be discussed, based on a proposed EC directive, ${ }^{27}$ not being subject of this paper. In contrast, FAT is to be levied on the particular items of the value added produced by banks, that is, on banking profit and bankers remuneration. While referring to bonuses, it may function as a surcharge.

Bank leverage tax has been introduced at a national level in a number of the EU Member States. It can be seen from comparative data that the tax rates applied in Hungary are extremely high. It is also noteworthy that it is only Germany and Sweden where the levy is dedicated to a special stability fund. In that respect, the bank levies introduced in other countries seem to be less justified.

Hungary is also unique in the sense that the Hungarian crisis tax is introduced temporarily only, that is, for the period of 2010-12. This tax was introduced in the autumns of 2010 retroactively as applicable as of 1 January 2010. The burden of tax should be reduced by $50 \%$ for 2012 as a result of an agreement the Hungarian Government concluded with the Hungarian Bankers Association. ${ }^{28}$ From 2013, this tax should be replaced by a permanent financial transaction tax, not discussed here. Notably, it cannot be compared to the Commission-based FTT proposal. ${ }^{29}$

The bank levy issue is to be studied in the context of other taxes like corporate income tax and local taxes. Securities transaction taxes are also noteworthy. The right to elect for VAT, payroll taxes and insurance premium taxes if any are also important while making an assessment of the taxation of the financial sector.

\section{(ii) Regulatory framework}

The major aspects of the assessment of a regulatory framework relevant to the special taxation of financial markets can be highlighted as follows:

- "ex ante" versus "ex post" measures;

- destination of proceeds;

- personal scope of taxation;

${ }^{26} \operatorname{COM}(2010) 549$ final.

27 Proposal for a Council Directive on a common system of financial transaction tax and amending Directive 2008/7/EC, COM(2011) 594 final. The Commission submitted a new proposal under No. COM(2013) 71 final on 14 February 2013, now based on the enhanced cooperation in the area of financial transaction tax that is to be introduced in eleven Member States.

${ }^{28}$ Understanding between the Hungarian Government and the Hungarian Bankers' Association of 15 December 2011.

${ }^{29}$ For the analysis of the current crisis tax of financial enterprises and the financial transactions tax, the law on which has been passed, but will be applicable from the next year no, see Deak, D.: Bizarr magyar pénzügyi adók (Bizarre Hungarian financial taxes). Figyelö, (2012) 31, 54-55. 
- taxable basis;

- tax rates;

- possible prohibition of deduction for corporate tax purposes; and

- double charging.

While designing a regulatory framework, the first question to be answered is whether and if so, how to apply "ex ante" measures. This is a major challenge for tax policy designers because the normal approach would be to stick to the legal certainty principle as introduced already by Adam Smith. In this context, "ex post" measures, lacking a normative basis should be excluded. Meeting the global financial crisis, it seems to be utmost difficult to predict the future, however. Therefore, legislators would like to reserve themselves to be flexible. Even if "ex ante" measures are applied, they are combined with "ex post" ones.

For example, the French regulatory supervision authority may modify the minimum regulatory capital rules within three years after the payment of the bank levy regarding a given tax year. Then, the bank levy for such a tax year can be retroactively increased or decreased accordingly. By this feature of flexibility, it can also be pointed out that tax law is closely connected with non-tax regulations. Tax and non-tax tools of regulation are aimed at the same subject, that is, at the formation of the own capital for capital adequacy purposes, and they have been introduced with the same purpose, that is, with that of protecting the own capital of financial enterprises, comparable to the total risk-weighted assets. The French tax is levied on the risk-weighted assets that are taken into account with calculating the own capital for the purposes of capital adequacy standards. In Germany, additional contributions can be requested from credit institutions where the resources of the restructuring fund that is financed by the bank levy prove to be insufficient to cover the measures, proposed to be taken to stabilise the financial sector. Tax measures can be considered as the indirect means of control, as compared to the direct means of regulation of the own capital for capital adequacy purposes in the sense that while the latter cannot be shunned unless a portion of bank assets is eventually withdrawn, the payment of the bank levy can be avoided, provided that the taxpayer is not engaged in certain taxable events.

The "ex post" means of regulation are claw back measures. This way, the financial service-providers are requested to reimburse the state for the cost of stabilising the financial market. The liability to pay is thus developed subsequent to the taxable event. This also means that the burden of payment cannot be predicted. Sticking to the requirement that the introduction of tax liability must be based on legal provisions that provide for the liability to pay tax in advance, claw back measures cannot be considered longer as taxes.

Another constraint on the applicability of taxation is a financial crisis responsibility fee as known by a proposal of President Obama. The fee is directly compensated by the stabilisation measures to be taken if necessary. It is an "ex ante" measure. It can be considered, as discussed, as an insurance fee rather than a tax, however. Notably, the burden of fee can, and would likely, be passed over to the taxpayer's clients.

It can be seen from the destination of the proceeds to be collected that the function of raising money is associated with the goal of exercising influence on the taxpayer's conduct. This means that the tax revenue can fall once the legislative measure reaches its goal, that is, to discourage the participants of the financial market from getting engaged in excessive financial activity. This is not yet a problem because the major goal is to address externalities, that is, to manage systemic risks connected with the financial activity.

A bank tax, the revenue of which flows to the general state budget cannot be strictly considered as a bank leverage tax, or a bank levy. This is the case with the Hungarian crisis 
tax of financial enterprises, not being targeted at the stabilisation of financial intermediaries. In fact, there was no Hungarian financial institution that would have been subject to any recovery measure taken by the state. The Hungarian tax has been introduced to stabilise the state budget. The main goal is to manage the public debt that tended to be around about $80 \%$ of the annual GDP in the recent four or five years. The Hungarian tax is thus not a tax of the crisis of banks, but of the crisis of the state budget.

While designing the personal scope of taxation, it is important to remember the danger of relocation. This is in particular an issue with transaction taxes, but bank levies or a financial activity tax can also be affected. Relocation is a variant of deadweight losses. Thus, the addressee of a tax law may elude taxation by ceasing to act or leaving for a territory, which is outside the scope of taxation. ${ }^{30}$ Relocation is also problematic because the financial institutions that are not big and mobile enough would not be able to move. As a consequence, the financial institutions that represent the moral hazard of "too big to fail" would escape tax, but the financial institutions that do not signify such a danger would be hit by it. ${ }^{31}$

Designing the scope of a bank leverage tax, it can be logical to exclude from taxation inter-banking business, on the one hand. It is also a matter of choice if taxation be extended not only to deposit institutions, but to the enterprises of investment banking as well. On the other hand, it seems to be reasonable to treat financial enterprises as taxpayers on a consolidated basis. It may depend on the jurisdiction how this idea is to be implemented. For example, in the UK, it is obvious that large companies are treated as groups for civil law, accounting and tax purposes. On the European continent, this is not so much evident, however. For instance, in France, the bank leverage tax is levied on a consolidated basis, provided, however, that the head of group is established in France. In case of the UK levy, there is no such requirement. In Germany, the bank levy (Bankenabgabe) is levied on single entities.

Commercial reality dictates us that groups should be subject to a bank levy rather than single entities. For the tax lawyer it may cause a problem, however, because it may be difficult to treat commercial entities (groups) that are not single legal entities, or they are, but in certain conditions only. For example, the mechanics of a double tax convention is normally designed to treat single taxpayers. While the tax liability of affiliated entities is calculable, it can be extremely difficult if not impossible to apply the rules of allocating the taxation power of two or more states. Although a tax treaty may provide for indirect credit, the personal scope of treaty and the notion of fiscal residence must be determined in case of single entities. Where the personal scope of taxation is directly extended to groups, overlapping of the taxation power of more than one state cannot be avoided.

A bank leverage tax can be levied on the balance sheet total assets, on the balance sheet total liabilities, on the turnover (sales receipts), on profit, or on any other form of the value added produced, e.g. on the bonuses paid to bank managers. Notably, it cannot be levied on single transactions. It would already be a financial transaction tax, not subject of this paper. Nevertheless, the rationale for a financial transaction tax is the same, that is, to

${ }^{30}$ Page, R. T.: Foolish Revenge or Shrewd Regulation? Financial-Industry Tax Law Reforms Proposed in the Wake of the Financial Crisis. Tulane Law Review, 85 (2010-2011), 200.

${ }^{31}$ Beck, H.-Prinz, A.: Moralisierung in der Steuerpolitik: Was taugen die jüngsten Steuervorschläge? op. cit. 822 . 
address systemic risks by deterring financial intermediaries from getting engaged in any excessive financial activity.

A transaction tax seems to be more appropriate for sorting out risks that are associated with the various types of transactions (e.g. those with derivatives). It is then easier to pass over the burden of tax. A bank leverage tax is a tax of the financial service-provider itself, and it is not clear if the burden of tax can be passed over. Where it is levied on risk-weighted assets, its connectedness with banking regulations is apparent. Where tax is levied on liabilities, it is designed to adjust the taxpayer's status of indebtedness. A turnover-based tax seems to be less viable for the purposes of a bank leverage tax. This is because the identification of the systemic risks is not really connected with the development of the turnover. The Hungarian crisis tax of financial enterprises is levied on the turnover in case of the financial enterprises other than credit institutions. This can be explained by the fact that the Hungarian tax is not a bank leverage tax.

Taking into account the goal to be associated with the introduction of a bank leverage tax, that is, to address externalities, it seems to be logical to apply progressive rates and caps. The main idea is to filter out risks. Therefore, innocent activities (long-term deposits, claims instituted against the public, etc.) can be excluded, or be subject to lower taxation. The harshness of taxation can be alleviated in case of large-volume transactions by applying caps or ceilings. Otherwise taxation would cause unnecessary restrictions on the free movement of capital. Was this the case, it could hardly be possible to justify the restrictive tax measure, considering the proportionality principle. Transactions with financial derivatives should be subject to lower rates as they produce a large volume, and higher-rate taxation would deteriorate this business what cannot be the legislator's goal. Progression in taxation makes nevertheless a signal to taxpayers of how they orient themselves. They are thus recommended to avoid getting engaged in excessive financial activity.

One can argue that the burden of a bank leverage tax should be treated as an expense for corporate tax purposes. This is not the case in certain jurisdictions (e.g. in Germany), however. The tax would seem unjust in particular in cases where the taxpayer sustains losses. The Hungarian tax is extremely comprehensive because the crisis tax of financial enterprises is combined with a crisis tax of credit institutions. The latter is levied on profit at a $30 \%$ rate. The former can be reduced by the profit-based tax, if any. Where there is no basis for profit tax, it is the total balance sheet assets related tax of financial enterprises that is applicable at a standard rate of $0.53 \%$ with credit institutions. The crisis tax of financial enterprises can be deducted from the corporate tax base.

While the taxation of the financial sector is designed during the global financial crisis, it is important not only to make an assessment whether the financial industry is overtaxed. Similarly, it is also vital to take into account that debt bias has contributed to the crisis. From this perspective, all the measures are welcome that may resolve the problem of asymmetry in the tax treatment of debt and equity. In this respect, one can mention about the following tools: thin capitalisation regimes, comprehensive business income tax rules with limited deduction opportunity ("CBIT"), and the allowance for corporate equity ("ACE"). The expanded use of fair valuation rules may also help with this problem. However, they may also increase instability in the legal regulation, lacking a cash basis for accounting. 
Besides, it is noteworthy that the extensive application of fiscal incentives can be prejudiced because they may well have contributed to deepening of the crisis. In this respect, the following can be highlighted: ${ }^{32}$

- tax preferences applicable to capital income and the proliferation of employee stock option plans;

- the preferential tax regimes that were applicable to housing;

- tax planning opportunities relating to the products of structured finance; and

- proliferation of tax havens and harmful tax competition.

The problem of double charging arises from the overlapping of taxation that is based both on personal and territorial scope. While the foreign operating branches of domestic financial enterprises are taxable according to the concept of worldwide taxation, the domestically operating branches of foreign enterprises are also taxable, now by means of the territorial scope of taxation. The problem of overlapping is exacerbated by the fact that the bank levy may be applicable to groups (like in the UK or France). This is why the UK has concluded double tax agreements on the relief from the double charging of bank levies with France and Germany. This is a topic that is to be discussed in a separate paper.

32 Debt Bias and Other Distortions: Crisis-Related Issues in Tax Policy; Prepared by the IMF Fiscal Affairs Department; Approved by Carlo Cottarelli; 12 June 2009, para. 21, p. 14, para. 29, p. 16 , para. 32 , p. 17 , para. 49 , p. 24 para. 53 , p. 25 , para. 57 , p. 26 , para. 63 , p. 28 , para. 68 , p. 30. 